\title{
Penerapan Metode Metafora Berbantu Media Gambar pada Pelajaran PAI untuk Meningkatkan Keaktifan Belajar Siswa Kelas V SD Negeri 013 Pulau Kalimanting
}

\author{
Putra Hendri $^{1}$, Johan Andriesgo ${ }^{2}$, dan Andrizal ${ }^{3}$ \\ ${ }^{1}$ Prodi Pendidikan Agama Islam FTK UNIKS \\ ${ }^{2}$ Prodi Manajemen Pendidikan Islam STAIN Bengkalis \\ ${ }^{3}$ Prodi Pendidikan Agama Islam FTK UNIKS \\ E-mail: putrahendri212a@gmail.com
}

\begin{abstract}
Abstrak
Keberhasilan seorang siswa juga merupakan keberhasilan seorang guru. Hal itu dikarenakan guru memiliki sebuah tanggung jawab atas keberhasilan anak didiknya. Keberhasilan siswa dapat dilihat dari keaktifannya dalam proses belajar mengajar. Sehubungan dengan mata pelajaran PAI yang lebih memerlukan penjelasan agar siswa lebih memahami materi yang disampaikan guru, metode metafora menjadi salah satu solusinya. Metode pembelajaran ini menjelaskan sesuatu dengan mengungkapan sesuatu yang lain dimana masih memiliki kedekatan sifat atau sesuatu yang ingin ditonjolkan. Selain untuk mendekatkan makna satu kata dengan kata yang lain, dengan menggunakan metode metafora akan dapat memberikan proyeksi animistis. Dengan memberikan proyeksi ini sesuatu yang mungkin tidak dapat dijelaskan atau sesuatu yang abstrak, akan menjadi lebih jelas dan konkret. Dari hasil penelitian terdapat peningkatan keaktifan belajar mata pelajaran PAI pada siswa kelas $\mathrm{V}$ melalui penerapan metode metafora berbantu media gambar. Hal ini dibuktikan sejak Pra Siklus nilai rata-rata keaktifan belajar siswa hanya 41,25\%. Pada Siklus I nilai rata-rata keaktifan belajar siswa 61,25\%. Pada Siklus II nilai rata-rata keaktifan belajar siswa naik menjadi $82,50 \%$. Pada Siklus III nilai rata-rata keaktifan belajar siswa naik menjadi $95 \%$. Sehingga dapat disimpulkan bahwa metode pembelajaran metafora dapat meningkatkan keaktidan siswa Kelas V SD Negeri 013 Pulau Kalimanting Kecamatan Benai.
\end{abstract}

Kata kunci: Metode Metafora, Bantuan Media gambar, Keaktifan Belajar.

\section{PENDAHULUAN}

Pendidikan adalah satu usaha yang dilaksanakan secara sadar dan bertujuan untuk mengembangkan kualitas manusia. Sebagai suatu kegiatan yang sadar akan tujuan, maka dalam pelaksanaannya berada dalam suatu proses yang berkesinambungan dalam setiap jenis dan jenjang pendidikan, semuanya berkaitan dalam suatu sistem pendidikan yang integral (Djamarah, 2000: 22).

Kemudian pendidikan merupakan proses interaksi antara guru dengan siswa. Dalam interaksi tersebut guru sebagai figur sentral melakukan kegiatan yang disebut mengajar, dan siswa sebagai subjek melakukan suatu kegiatan yang disebut belajar. Interaksi antara guru dengan siswa ini disebut Proses Belajar Mengajar (PBM) yang biasanya berlangsung dalam sebuah lembaga pendidikan baik formal maupun non formal.

Ketajaman guru dalam menganalisis hal-hal yang berkaitan dengan siswa, lingkungan kelas, sangatlah diperlukan karena mengajar bukanlah semata persoalan menceritakan, belajar bukanlah konsekuensi otomatis dari perenungan informasi ke dalam benak siswa. Karena belajar memerlukan keterlibatan mental dan kerja sama kelompok yang bisa membuahkan hasil belajar, kegiatan belajar yang langgeng hanyalah kegiatan belajar aktif (Silberman, 2004:1).

Seorang guru dapat meningkatkan keaktifan belajar siswa dalam mengikuti materi yang diajarkan dengan sebuah metode dan strategi-strategi belajar yang ada yang telah disesuaikan dengan situasi dan kondisi yang ada. Bagi guru keberhasilan siswa berpartisipasi dalam belajar juga merupakan sebuah keberhasilan sebagai pengajar.

Keaktifan siswa dalam proses pembelajaran terjadi pada siswa setelah adanya proses berfikir. Berbicara mengenai pengaruh dari pada metode pembelajaran terhadap keaktifan siswa, terlebih dahulu perlu diketahui bahwa yang diharapkan setelah terjadinya proses belajar mengajar berlangsung akan terjadi efek yaitu efek kognitif, efek afektif dan efek behavioral (Muhaimin dan Abdul, 2003: 83).

Berpijak pada uraian diatas, dapatlah ditarik asumsi bahwa pengaruh dari pada metode pembelajaran terhadap keaktifan siswa dalam mengikuti proses pembelajaran cukup besar yang mencakup:

a.Adanya perubahan pada pemahaman, pengetahuan dan pengertian

b. Adanya perubahan pada sikap dan tingkah laku

c. Adanya perubahan pada pengamalan, tindakan dan perbuatan. 
SD Negeri 013 Pulau Kalimanting menyelenggarakan pembelajaran dengan menggunakan kurikulum KTSP 2006 dan khusus pendidikan agama Islam diajarkan 3 jam pelajaran setiap minggunya di setiap tingkat kelas. dari pengamatan awal yang penulis laksanakan khususnya di kelas $V$ saat proses pembelajaran berlangsung, ada beberapa gejala yang diantaranya adalah :

1. Guru kurang mampu mengajar dengan metode yang menarik dan menyenangkan sehingga siswa terlihat tidak serius untuk belajar.

2. Ketika guru memberikan materi dengan perumpamaan siswa kurang mampu memahami dengan baik.

3. Ketika proses pembelajaran sedang berlangsung masih banyak siswa yang keluar masuk kelas

4. Ketika diberikan pertanyaan dalam sesi apersepsi siswa tidak ada yang bertanya karena belum memahami materi yang disampaikan.

5. Siswa belum bisa aktif dalam proses pembelajaran PAI dan masih banyak yang pasif dengan hanya mendengarkan keterangan guru.

6. Guru kurang melibatkan siswa dalam kegiatan pembelajaran PAI sehingga siswa lebih terkesan pasif dikarenakan proses pembelajaran sepenuhnya dikendalikan oleh guru PAI (teacher centered).

Melihat kondisi seperti ini, tentu diperlukan suatu metode atau strategi yang menarik dan menyenangkan sehingga proses pembelajaran lebih efektif dan keaktifan belajar yang diinginkan dapat tercapai. Metode metafora ini akan memberikan gambaran yang lain, dimana sesuatu yang akan diungkapkan dapat dijelaskan dengan ungkapan sesuatu yang lain yang tentunya masih memiliki kedekatan sifat atau sesuatu yang ingin ditonjolkan (Rena dan Austian, 2010: 253). Selain untuk mendekatkan makna satu kata dengan kata yang lain, maka dengan menggunakan metode metafora akan dapat memberikan proyeksi animistis, dengan memberikan proyeksi ini sesuatu yang mungkin tidak dapat dijelaskan atau sesuatu yang abstrak, akan menjadi lebih jelas dan konkret (Rena dan Austian, 2010: 254).

Oleh karena itu dengan menerapkan metode metafora dengan bantuan media gambar diharapkan keaktifan belajar siswa pada bidang studi pendidikan agama islam siswa semakin membaik dari sebelumnya. Dengan melihat beberapa gejala yang ditemukan dilapangan, maka penulis tertarik untuk melaksanakan penelitian ilmiah dengan judul "Penerapan Metode Metafora dengan Bantuan Media Gambar pada Mata Pelajaran Pendidikan Agama Islam untuk Meningkatkan Keaktifan Belajar Siswa Kelas V di SD Negeri 013 Pulau Kalimanting Kecamatan Benai”.

\section{METODE/EKSPERIMEN}

Penelitian ini adalah penelitian tindakan kelas yang sengaja dilakukan untuk mencermati kegiatan belajar dalam sebuah kelas secara bersamaan dengan penerapan metode metafora dengan bantuan media gambar kelas V di SD Negeri 013 Pulau Kalimanting, dengan jumlah siswa 8 orang yang terdiri dari 2 orang siswa laki-laki dan 6 orang siswi perempuan.

Data dalam penelitian ini diperoleh melalui lembar observasi, test, wawancara dan dokumentasi kemudian di analisis. Data dalam penelitian ini akan dianalisis secara kualitatif, meliputi tiga unsur yaitu reduksi data, penyajian data dan penarikan kesimpulan yang merupakan intisari dari analisis tentang dampak dari penelitian tindakan kelas.

\section{Hasil}

\section{HASIL DAN PEMBAHASAN}

Dalam penelitian ini dilakukan dalam empat siklus pembelajaran yaitu: Pra Siklus 1 kali pertemuan, Siklus I dilaksanakan 1 kali pertemuan, siklus II dilaksanakan 1 kali pertemuan, dan siklus III dilaksanakan satu kali pertemuan.

Pada pra siklus untuk mendapatkan perbandingan peningkatan keaktifan belajar siswa sebelum melaksanakan penelitian, peneliti mengumpulkan data dan informasi mengenai subjek penelitian. Data-data yang dikumpulkan antara lain, hasil observasi metode yang digunakan guru dalam pembelajaran dan keaktifan belajar siswa pada mata pelajaran PAI di kelas V SD Negeri 013 Pulau Kalimanting, adapun hasil observasinya dapat di lihat pada tabel 1. 
Tabel. 1 Pra SiklusSebelum Penggunaan Metode Metaforadengan bantuan Media Gambar

\begin{tabular}{|c|c|c|c|}
\hline \multirow{2}{*}{ No } & \multirow{2}{*}{ Aspek yang di observasi } & \multicolumn{2}{|c|}{ Jawaban } \\
\hline & & Sdh & BIm \\
\hline 1 & $\begin{array}{l}\text { Guru mencari sifat heroik dalam materi dengan cara melihat topik } \\
\text { yang akan dipelajari. }\end{array}$ & & $\sqrt{ }$ \\
\hline 2 & $\begin{array}{c}\text { Guru memberikan pancingan agar siswa lebih ingin mengetahui topik } \\
\text { yang akan dipelajari dengan cara menayangkan gambar. }\end{array}$ & & $\sqrt{ }$ \\
\hline 3 & $\begin{array}{l}\text { Guru mengucapkan narasi kalimat yang tepat mengumpamakan } \\
\text { materi yang akan dipelajari sambil memasang gambar. }\end{array}$ & & $\sqrt{ }$ \\
\hline 4 & $\begin{array}{l}\text { Guru meminta siswa untuk menyusun kalimat narasi untuk membuat } \\
\text { ilustrasi terbaik dari materi atau gambar yang akan dipelajari }\end{array}$ & & $\sqrt{ }$ \\
\hline 5 & $\begin{array}{c}\text { Siswa dengan cermat membuat perumpamaan sesuai dengan materi } \\
\text { atau gambar yang di pajang didepan kelas }\end{array}$ & & $\sqrt{ }$ \\
\hline 6 & $\begin{array}{l}\text { Siswa secara bergantian menampilkan kalimat narasi atau } \\
\text { perumpamaan yang telah mereka susun sebelumnya yang } \\
\text { berhubungan dengan materi dan gambar didepan kelas. }\end{array}$ & & $\sqrt{ }$ \\
\hline 7 & $\begin{array}{l}\text { Siswa secara bergantian saling menanyakan kepada teman } \\
\text { sekelasnya memberikan arti gambar yang telah mereka buat. }\end{array}$ & & $\sqrt{ }$ \\
\hline 8 & $\begin{array}{l}\text { Guru meluruskan makna-makna yang telah di bacakan siswa } \\
\text { sehingga siswa lebih memahami makna gambar tersebut }\end{array}$ & & $\sqrt{ }$ \\
\hline 9 & $\begin{array}{c}\text { Guru menanyakan kesulitan siswa dalam memahami perumpamaan } \\
\text { atau gambar yang telah dipelajari }\end{array}$ & $\sqrt{ }$ & \\
\hline 10 & $\begin{array}{c}\text { Guru bersama siswa membuat kesimpulan sebagai hasil akhir } \\
\text { pembelajaran yang telah dilaksanakan }\end{array}$ & $\sqrt{ }$ & \\
\hline & Jumlah & 20 & 80 \\
\hline
\end{tabular}

Pada observasi pra siklus terlihat bahwa aktifitas guru dan siswa dalam melaksanakan pembelajaran $20 \%$ saja persentasenya yang melakukan langkah-langkah metode metafora dengan bantuan media gambarsementara $80 \%$ belum mampu dilakukan dalam pembelajaran pendidikan agama islam.Pada pra siklus ini siswa memiliki keaktifan belajar rata-rata $41,55 \%$. Hal ini dapat dilihat secara seksama sebagaimana hasil keaktifan belajar siswa pada bidang studi pendidikan agama islam sebagaimana tabel 2.

Tabel. 2 Pra Siklus Keaktifan Belajar Pendidikan Agama Islam SebelumPenerapan Metode Metafora dengan bantuan Media Gambar

\begin{tabular}{|c|c|c|c|}
\hline No & Aspek Keaktifan Belajar Siswa & Frek & $\%$ \\
\hline 1 & $\begin{array}{c}\text { Memperhatikan dan mendengarkan keterangan guru secara } \\
\text { seksama }\end{array}$ & 4 & 50 \\
\hline 2 & $\begin{array}{c}\text { Memahami strategi atau teknik pemecahan masalah yang } \\
\text { diajarkan guru }\end{array}$ & 3 & 37,50 \\
\hline 3 & Turut serta dalam melaksanakan tugas belajar. & 3 & 37,50 \\
\hline 4 & Terlibat dalam pemecahan masalah. & 4 & 50 \\
\hline 5 & $\begin{array}{c}\text { Bertanya kepada siswa lain atau kepada guru apabila tidak } \\
\text { memahami persoalan yang dihadapinya. }\end{array}$ & 3 & 37,50 \\
\hline 6 & $\begin{array}{c}\text { Berusaha mencari berbagai informasi yang diperlukan untuk } \\
\text { pemecahan masalah. }\end{array}$ & 2 & 25,00 \\
\hline 7 & Melaksanakan diskusi kelompok sesuai petunjuk guru. & 5 & 62,50 \\
\hline 8 & Menilai kemampuan dirinya dan hasil-hasil yang diperolehnya. & 3 & 37,50 \\
\hline 9 & Melatih diri dalam memecahkan soal atau masalah sejenis. & 2 & 25,00 \\
\hline 10 & Menggunakankemampuandiperolehuntukmenyelesaikan tugas \\
atau persoalan yang dihadapi & 4 & 50 \\
\hline & Rata-rata persentase keaktifan belajar siswa & & 41,25 \\
\hline
\end{tabular}

Dari Tabel diatas terlihat bahwa siswa dalam mengikuti pelajaran kurang aktif, kenyataan ini terlihat disaat siswa di berikan kesempatan untuk menjawab soal, mereka belum mampu memperoleh nilai yang baik yaitu nilai yang mencapai Kriteria Ketuntasan Minimal. Selain itu mereka tidak mampu menjawab pertanyaan perumpamaan yang di ajukan guru ketika proses belajar mengajar, ini menandakan bahwa guru belum bisa secara maksimal mengukur dan menyesuaikan kemampuan kognitif, afektif serta psikomotor siswa tentang materi Pendidikan Agama Islam yang dipelajari, hasil 
belajar Pendidikan Agama Islam yang diharapkan belum mencapai target yang diinginkan. Pada pra Siklus ini siswa hanya memiliki keaktifan belajar rata-rata $41,55 \%$.

Oleh karena itu untuk meningkatkan keaktifan belajar pendidikan Islam, maka peneliti ingin menerapkan metode Metafora dengan bantuan Media Gambar pada siswa kelas Vdi SD Negeri 013 Pulau Kalimanting Kecamatan Benai maka dirasa perlu diadakan observasi per siklus yang di awali dengan siklus I yaitu awal atau permulaan guru Pendidikan Agama Islam menerapkannya dalam proses pembelajaran sebagaimana yang dapat kita lihat pada tabel berikut ini :

Tabel. 3 Siklus I Awal Penerapan Metode Metafora dengan bantuan Media Gambar

\begin{tabular}{|c|c|c|c|}
\hline \multirow{2}{*}{ No } & \multirow{2}{*}{ Aspek yang di observasi } & \multicolumn{2}{|c|}{ Jawaban } \\
\hline & & Sdh & $\mathrm{Blm}$ \\
\hline 1 & $\begin{array}{l}\text { Guru mencari sifat heroik dalam materi dengancara melihat topik yang } \\
\text { akan dipelajari. }\end{array}$ & $\sqrt{ }$ & \\
\hline 2 & $\begin{array}{c}\text { Guru memberikan pancingan agar siswa lebih ingin mengetahui topik } \\
\text { yang akan dipelajari dengan cara menayangkan gambar. }\end{array}$ & $\sqrt{ }$ & \\
\hline 3 & $\begin{array}{c}\text { Guru mengucapkan narasi kalimat yang tepat mengumpamakan materi } \\
\text { yang akan dipelajari sambil memasang gambar. }\end{array}$ & $\sqrt{ }$ & \\
\hline 4 & $\begin{array}{c}\text { Guru meminta siswa untuk menyusun kalimat narasi untuk membuat } \\
\text { ilustrasi terbaik dari materi atau gambar yang akan dipelajari }\end{array}$ & $\sqrt{ }$ & \\
\hline 5 & $\begin{array}{c}\text { Siswa dengan cermat membuat perumpamaan sesuai dengan materi } \\
\text { atau gambar yang di pajang didepan kelas }\end{array}$ & $\sqrt{ }$ & \\
\hline 6 & $\begin{array}{l}\text { Siswa secara bergantian menampilkan kalimat narasi atau } \\
\text { perumpamaan yang telah mereka susun sebelumnya yang } \\
\text { berhubungan dengan materi dan gambar didepan kelas. }\end{array}$ & $\sqrt{ }$ & \\
\hline 7 & $\begin{array}{l}\text { Siswa secara bergantian saling menanyakan kepada teman } \\
\text { sekelasnya memberikan arti gambar yang telah mereka buat. }\end{array}$ & $\sqrt{ }$ & \\
\hline 8 & $\begin{array}{l}\text { Guru meluruskan makna-makna yang telah di bacakan siswa sehingga } \\
\text { siswa lebih memahami makna gambar tersebut }\end{array}$ & $\sqrt{ }$ & \\
\hline 9 & $\begin{array}{l}\text { Guru menanyakan kesulitan siswa dalam memahami perumpamaan } \\
\text { atau gambar yang telah dipelajari }\end{array}$ & $\sqrt{ }$ & \\
\hline 10 & $\begin{array}{c}\text { Guru bersama siswa membuat kesimpulan sebagai hasil akhir } \\
\text { pembelajaran yang telah dilaksanakan }\end{array}$ & $\sqrt{ }$ & \\
\hline & Jumlah & 10 & 0 \\
\hline
\end{tabular}

Pada pertemuan kedua atau Siklus I penggunaan metode metafora dengan bantuan media gambar pada siswa sudah mampu $10 \%$, jadi persentasenya naik sementara $80 \%$ dan tidak ada lagi yang belum mampu dilakukan oleh siswa dalam pembelajaran Pendidikan Agama Islam dengan metode tersebut. Setelah diadakan ulangan harian pada siklus I ini dapat dilihat siswa sudah mulai antusias untuk mengikuti pembelajaran Pendidikan Agama Islam, hal ini terlihat keaktifan belajar siswa mengalami peningkatan dari pada sebelumnya, untuk lebih jelas dapat dilihat pada tabel 4.

Tabel. 4 Siklus I Keaktifan Belajar Pendidikan Agama Islam AwalPenerapan Metode Metaforadengan batuan Media Gambar

\begin{tabular}{|c|c|c|c|}
\hline No & Aspek Keaktifan Belajar Siswa & Frek & $\%$ \\
\hline 1 & $\begin{array}{c}\text { Memperhatikan dan mendengarkan keterangan guru secara } \\
\text { seksama }\end{array}$ & 5 & 62,50 \\
\hline 2 & $\begin{array}{l}\text { Memahami strategi atau teknik pemecahan masalah yang } \\
\text { diajarkan guru }\end{array}$ & 4 & 50,00 \\
\hline 3 & Turut serta dalam melaksanakan tugas belajar. & 5 & 62,50 \\
\hline 4 & Terlibat dalam pemecahan masalah. & 6 & 75,00 \\
\hline 5 & $\begin{array}{c}\text { Bertanya kepada siswa lain atau kepada guru apabila tidak } \\
\text { memahami persoalan yang dihadapinya. }\end{array}$ & 4 & 50,00 \\
\hline 6 & $\begin{array}{l}\text { Berusaha mencari berbagai informasi yang diperlukan untuk } \\
\text { pemecahan masalah. }\end{array}$ & 5 & 62,50 \\
\hline 7 & Melaksanakan diskusi kelompok sesuai petunjuk guru. & 6 & 75,00 \\
\hline 8 & Menilai kemampuan dirinya dan hasil-hasil yang diperolehnya. & 5 & 62,50 \\
\hline 9 & Melatih diri dalam memecahkan soal atau masalah sejenis. & 4 & 50,00 \\
\hline 10 & $\begin{array}{c}\text { Menggunakankemampuan diperoleh untukmenyelesaikan tugas } \\
\text { atau persoalan yang dihadapi }\end{array}$ & 5 & 62,50 \\
\hline \multicolumn{3}{|c|}{ Rata-rata persentase keaktifan belajar siswa } & 61,25 \\
\hline
\end{tabular}


Dari hasil evaluasi nilai keaktifan belajar siswa naik dari $41,25 \%$ menjadi $61,25 \%$ terlihat jelas bahwa siswa sudah mulai aktif menjawab perumpamaan yang menggunakan media gambar dalam pembelajaran Pendidikan Agama Islam.

Maka sebagai guru profesional, guru Pendidikan Agama Islam terus berupaya memperbaiki keaktifan belajar siswa dengan cara kembali mengadakan refleksi pada Siklus II sebagai lanjutan siklus I agar hasil yang didapatkan lebih sempurna sebagaimana pada siklus II dapat dilihat pada tabel 5.

Tabel. 5 Siklus II Penggunaan Metode Metaforadengan bantuan Media Gambar

\begin{tabular}{|c|c|c|c|}
\hline \multirow{2}{*}{ No } & Aspek yang di observasi & \multicolumn{2}{|c|}{ Jawaban } \\
\cline { 3 - 4 } & $\begin{array}{c}\text { Gdh } \\
\text { auru mencari sifat heroik dalam materi dengancara melihat topik yang } \\
\text { akan dipelajari. }\end{array}$ & $\sqrt{ }$ & \\
\hline 2 & $\begin{array}{c}\text { Guru memberikan pancingan agar siswa lebih ingin mengetahui topik } \\
\text { yang akan dipelajari dengan cara menayangkan gambar. }\end{array}$ & $\sqrt{ }$ & \\
\hline 3 & $\begin{array}{c}\text { Guru mengucapkan narasi kalimat yang tepat mengumpamakan materi } \\
\text { yang akan dipelajari sambil memasang gambar. }\end{array}$ & $\sqrt{ }$ & \\
\hline 4 & $\begin{array}{c}\text { Guru meminta siswa untuk menyusun kalimat narasi untuk membuat } \\
\text { ilustrasi terbaik dari materi atau gambar yang akan dipelajari }\end{array}$ & $\sqrt{ }$ & \\
\hline 5 & $\begin{array}{c}\text { Siswa dengan cermat membuat perumpamaan sesuai dengan materi } \\
\text { atau gambar yang di pajang didepan kelas }\end{array}$ & $\sqrt{ }$ & \\
\hline 6 & $\begin{array}{c}\text { Siswa secara bergantian menampilkan kalimat narasi atau } \\
\text { perumpamaan yang telah mereka susun sebelumnya yang } \\
\text { berhubungan dengan materi dan gambar didepan kelas. }\end{array}$ & $\sqrt{ }$ & \\
\hline 7 & $\begin{array}{c}\text { Siswa secara bergantian saling menanyakan kepada teman } \\
\text { sekelasnya memberikan arti gambar yang telah mereka buat. }\end{array}$ & $\sqrt{ }$ & \\
\hline 8 & $\begin{array}{c}\text { Guru meluruskan makna-makna yang telah di bacakan siswa sehingga } \\
\text { siswa lebih memahami makna gambar tersebut }\end{array}$ & $\sqrt{ }$ & \\
\hline 9 & $\begin{array}{c}\text { Guru menanyakan kesulitan siswa dalam memahami perumpamaan } \\
\text { atau gambar yang telah dipelajari }\end{array}$ & $\sqrt{ }$ & \\
\hline 10 & $\begin{array}{c}\text { Guru bersama siswa membuat kesimpulan sebagai hasil akhir } \\
\text { pembelajaran yang telah dilaksanakan }\end{array}$ & $\sqrt{ }$ & \\
\hline & $\quad$ Jumlah & 10 & 0 \\
\hline
\end{tabular}

Pada pertemuan ketiga atau Siklus II bahwa dalam penerapan metode Metafora dengan bantuan Media Gambar siswa dan guru sudah mampu 100\% persentasenya, namun dari pengamatan sementara para siswa belum mampu mengikuti secara maksimal dalam pembelajaran PAI Dengan melihat siklus I yang telah dilaksanakan diatas, maka guru mengadakan refleksi kembali untuk mengevaluasi kegagalan siswa untuk aktif dalam pembelajaran pada Siklus II pada tabel 6.

Tabel. 6 Siklus II Keaktifan Belajar Pendidikan Agama Islam

Penerapan Metode Metaforadengan bantuan Media Gambar

\begin{tabular}{|c|c|c|c|}
\hline No & Aspek Keaktifan Belajar Siswa & Frek & $\%$ \\
\hline 1 & $\begin{array}{c}\text { Memperhatikan dan mendengarkan keterangan guru secara } \\
\text { seksama }\end{array}$ & 7 & 87,50 \\
\hline 2 & $\begin{array}{c}\text { Memahami strategi atau teknik pemecahan masalah yang } \\
\text { diajarkan guru }\end{array}$ & 6 & 75,00 \\
\hline 3 & Turut serta dalam melaksanakan tugas belajar. & 7 & 87,50 \\
\hline 4 & Terlibat dalam pemecahan masalah. & 7 & 87,50 \\
\hline 5 & $\begin{array}{c}\text { Bertanya kepada siswa lain atau kepada guru apabila tidak } \\
\text { memahami persoalan yang dihadapinya. }\end{array}$ & 6 & 75,00 \\
\hline 6 & $\begin{array}{c}\text { Berusaha mencari berbagai informasi yang diperlukan untuk } \\
\text { pemecahan masalah. }\end{array}$ & 6 & 75,00 \\
\hline 7 & Melaksanakan diskusi kelompok sesuai petunjuk guru. & 7 & 87,50 \\
\hline 8 & Menilai kemampuan dirinya dan hasil-hasil yang diperolehnya. & 7 & 87,50 \\
\hline 9 & Melatih diri dalam memecahkan soal atau masalah sejenis. & 6 & 75,00 \\
\hline 10 & Menggunakan kemampuan diperoleh untuk menyelesaikan \\
tugas atau persoalan yang dihadapi & 7 & 87,50 \\
\hline \multicolumn{2}{r|}{ Rata-rata persentase keaktifan belajar siswa } & & 82,50 \\
\hline
\end{tabular}

Putra Hendri ${ }^{1}$, Johan Andriesgo ${ }^{2}$, Andrizal $^{3}$ 
Dari hasil observasi yang diadakan siswa sudah memiliki keaktifan belajar yang baik pada bidang studi Pendidikan Agama Islam yaitu rata-rata dari 62,25\% naik menjadi 82,50\% sementara hanya sedikit siswa yang belum aktif. Hal ini terjadi karena metode metafora dengan bantuan media gambar ini mulai difahami oleh siswa kelas $\mathrm{V}$ dalam proses pembelajaran, sehingga siswa masih memerlukan banyak latihan. Namun demikian secara perlahan tapi pasti telah terlihat peningkatan keaktifan belajar siswa kelas $\mathrm{V}$ untuk mengikuti metode metafora dengan bantuan media gambar sebagaimana hasil siklus III seperti pada tabel 7 .

Tabel. 7 Siklus III Penggunaan Metode Metafora dengan bantuan Media Gambar

\begin{tabular}{|c|c|c|c|}
\hline \multirow{2}{*}{ No } & \multirow{2}{*}{ Aspek yang di observasi } & \multicolumn{2}{|c|}{ Jawaban } \\
\hline & & Sdh & BIm \\
\hline 1 & $\begin{array}{l}\text { Guru mencari sifat heroik dalam materi dengancara melihat topik } \\
\text { yang akan dipelajari. }\end{array}$ & $\sqrt{ }$ & \\
\hline 2 & $\begin{array}{l}\text { Guru memberikan pancingan agar siswa lebih ingin mengetahui topik } \\
\text { yang akan dipelajari dengan cara menayangkan gambar. }\end{array}$ & $\sqrt{ }$ & \\
\hline 3 & $\begin{array}{c}\text { Guru mengucapkan narasi kalimat yang tepat mengumpamakan } \\
\text { materi yang akan dipelajari sambil memasang gambar. }\end{array}$ & $\sqrt{ }$ & \\
\hline 4 & $\begin{array}{c}\text { Guru meminta siswa untuk menyusun kalimat narasi untuk membuat } \\
\text { ilustrasi terbaik dari materi atau gambar yang akan dipelajari }\end{array}$ & $\sqrt{ }$ & \\
\hline 5 & $\begin{array}{c}\text { Siswa dengan cermat membuat perumpamaan sesuai dengan materi } \\
\text { atau gambar yang di pajang didepan kelas }\end{array}$ & $\sqrt{ }$ & \\
\hline 6 & $\begin{array}{l}\text { Siswa secara bergantian menampilkan kalimat narasi atau } \\
\text { perumpamaan yang telah mereka susun sebelumnya yang } \\
\text { berhubungan dengan materi dan gambar didepan kelas. }\end{array}$ & $\sqrt{ }$ & \\
\hline 7 & $\begin{array}{l}\text { Siswa secara bergantian saling menanyakan kepada teman } \\
\text { sekelasnya memberikan arti gambar yang telah mereka buat. }\end{array}$ & $\sqrt{ }$ & \\
\hline 8 & $\begin{array}{l}\text { Guru meluruskan makna-makna yang telah di bacakan siswa } \\
\text { sehingga siswa lebih memahami makna gambar tersebut }\end{array}$ & $\sqrt{ }$ & \\
\hline 9 & $\begin{array}{c}\text { Guru menanyakan kesulitan siswa dalam memahami perumpamaan } \\
\text { atau gambar yang telah dipelajari }\end{array}$ & $\sqrt{ }$ & \\
\hline 10 & $\begin{array}{l}\text { Guru bersama siswa membuat kesimpulan sebagai hasil akhir } \\
\text { pembelajaran yang telah dilaksanakan }\end{array}$ & $\sqrt{ }$ & \\
\hline & Jumlah & 10 & 0 \\
\hline
\end{tabular}

Pada pertemuan keempat atau Siklus III penggunaan metode metafora dengan bantuan media gambar dimana siswa telah mampu $100 \%$ dimana secara keseluruhan siswa telah mampu mengikuti dan memahami dengan baik. Guru kembali mengadakan refleksi untuk mengevaluasi kegagalan pada Siklus II dan kembali mengobservasi keaktifan belajar siswa melalui penerapan metode metafora dengan bantuan media gambar pada siklus III pada tabel 8.

Tabel. 8 Siklus III Keaktifan Belajar Pendidikan Agama Islam Metode Metafora dengan bantuan Media Gambar

\begin{tabular}{|c|c|c|c|}
\hline No & Aspek Keaktifan Belajar Siswa & Frek & $\%$ \\
\hline 1 & $\begin{array}{c}\text { Memperhatikan dan mendengarkan keterangan guru secara } \\
\text { seksama }\end{array}$ & 8 & 100,00 \\
\hline 2 & $\begin{array}{c}\text { Memahami strategi atau teknik pemecahan masalah yang } \\
\text { diajarkan guru }\end{array}$ & 7 & 87,50 \\
\hline 3 & Turut serta dalam melaksanakan tugas belajar. & 8 & 100,00 \\
\hline 4 & Terlibat dalam pemecahan masalah. & 8 & 100,00 \\
\hline 5 & $\begin{array}{c}\text { Bertanya kepada siswa lain atau kepada guru apabila tidak } \\
\text { memahami persoalan yang dihadapinya. }\end{array}$ & 7 & 87,50 \\
\hline 6 & $\begin{array}{c}\text { Berusaha mencari berbagai informasi yang diperlukan untuk } \\
\text { pemecahan masalah. }\end{array}$ & 7 & 87,50 \\
\hline 7 & Melaksanakan diskusi kelompok sesuai petunjuk guru. & 8 & 100,00 \\
\hline 8 & Menilai kemampuan dirinya dan hasil-hasil yang diperolehnya. & 8 & 100,00 \\
\hline 9 & Melatih diri dalam memecahkan soal atau masalah sejenis. & 7 & 87,50 \\
\hline 10 & $\begin{array}{c}\text { Menggunakan kemampuan diperoleh untuk menyelesaikan tugas } \\
\text { atau persoalan yang dihadapi }\end{array}$ & 8 & 100,00 \\
\hline \multicolumn{2}{r|}{ Rata-rata persentase keaktifan belajar siswa } & & 95,00 \\
\hline
\end{tabular}

Dari hasil observasi yang dilakukan ternyata hasil rata-rata nilai keaktifan belajar siswa sudah mencapai 95,00\% siswa sudah ikut aktif dalam proses pembelajaran Pendidikan Agama Islam, 
hanya segelintir kecil yakni sekitar $5 \%$ saja yang belum berperan aktif. Berarti secara keseluruhan siswa penerapannya sudah maksimal, disini terlihat telah terbukti bahwa upaya guru meningkatkan keaktifan belajar siswa kelas $\mathrm{V}$ pada mata pelajaran Pendidikan Agama Islam melalui metode Metafora dengan bantuan Media Gambar di SD Negeri 013 Pulau Kalimanting Kecamatan Benai berhasil.

\section{Pembahasan}

Setelah diadakan observasi langsung kedalam kelas dengan melihat bagaimana guru menggunakan metode Metafora dengan bantuan Media Gambar disaat proses pembelajaran Pendidikan Agama Islam pada siswa kelas V, maka hasil rekapitulasi data observasi dapat dilihat pada tabel 9.

Tabel. 9 Hasil Rekapitulasi Observasi Hasil Penerapan Metode Metaforadengan bantuan Media Gambar

\begin{tabular}{|c|c|c|c|c|c|c|c|c|}
\hline \multirow{3}{*}{ No } & \multicolumn{2}{|c|}{ Pra Siklus } & \multicolumn{2}{|c|}{ Siklus I } & \multicolumn{2}{|c|}{ Siklus II } & \multicolumn{2}{|c|}{ Siklus III } \\
\hline & \multicolumn{2}{|c|}{ Opsi Jwbn } & \multicolumn{2}{|c|}{ Opsi Jwbn } & \multicolumn{2}{|c|}{ Opsi Jwbn } & \multicolumn{2}{|c|}{ Opsi Jwbn } \\
\hline & Sdh & $\mathrm{BIm}$ & Sdh & Blm & Sdh & $\mathrm{BIm}$ & Sdh & $\mathrm{Blm}$ \\
\hline 1 & & $\sqrt{ }$ & $\sqrt{ }$ & & $\sqrt{ }$ & & $\sqrt{ }$ & \\
\hline 2 & & $\sqrt{ }$ & $\sqrt{ }$ & & $\sqrt{ }$ & & $\sqrt{ }$ & \\
\hline 3 & & $\sqrt{ }$ & $\sqrt{ }$ & & $\sqrt{ }$ & & $\sqrt{ }$ & \\
\hline 4 & & $\sqrt{ }$ & $\sqrt{ }$ & & $\sqrt{ }$ & & $\sqrt{ }$ & \\
\hline 5 & & $\sqrt{ }$ & $\sqrt{ }$ & & $\sqrt{ }$ & & $\sqrt{ }$ & \\
\hline 6 & & $\sqrt{ }$ & $\sqrt{ }$ & & $\sqrt{ }$ & & $\sqrt{ }$ & \\
\hline 7 & & $\sqrt{ }$ & $\sqrt{ }$ & & $\sqrt{ }$ & & $\sqrt{ }$ & \\
\hline 8 & & $\sqrt{ }$ & $\sqrt{ }$ & & $\sqrt{ }$ & & $\sqrt{ }$ & \\
\hline 9 & $\sqrt{ }$ & & $\sqrt{ }$ & & $\sqrt{ }$ & & $\sqrt{ }$ & \\
\hline 10 & $\sqrt{ }$ & & $\sqrt{ }$ & & $\sqrt{ }$ & & $\sqrt{ }$ & \\
\hline & 20 & 80 & 10 & 0 & 10 & 0 & 10 & 0 \\
\hline
\end{tabular}

Dari hasil tabel diatas dapat dilihat hasilnya yaitu :

1. Pada awal atau hari pertama pra Siklus sebelum penerapan metode Metafora dengan bantuan Media Gambar siswa hanya mampu $20 \%$ saja persentasenya sementara $80 \%$ belum mampu dilakukan oleh siswa dalam pembelajaran Pendidikan Agama Islam.

2. Pada Siklus I atau kali kedua penerapan metode Metafora dengan bantuan Media Gambar siswa sudah mampu 100\% persentasenya dalam pembelajaran Pendidikan Agama Islam namun hasilnya belum maksimal.

3. Pada Siklus II Pada pertemuan ketiga atau kali ketiga penerapan metode Metafora dengan bantuan Media Gambar siswa telah mampu 100\% sementara hanya tinggal pematangan yang harus dilakukan oleh guru.

4. Pada Siklus III Pada pertemuan keempat atau hari terakhir penerapan metode Metafora dengan bantuan Media Gambar siswa telah mampu 100\%.

Sedangkan hasil rekapitulasi data test keaktifan belajar siswa kelas $\mathrm{V}$ pada bidang studi Pendidikan Agama Islam dapat dilihat pada tabel 10.

Tabel 10 Rekapitulasi Data Test Per SiklusKeaktifan Belajar Siswa Kelas V Bidang Studi PAI

\begin{tabular}{|c|c|c|c|c|c|c|c|c|}
\hline \multirow{2}{*}{ No } & \multicolumn{9}{|c|}{ Hasil Observasi Persiklus } \\
\cline { 2 - 9 } & \multicolumn{2}{|c|}{ Pra Siklus } & \multicolumn{3}{c|}{ Siklus I } & \multicolumn{2}{c|}{ Siklus II } & \multicolumn{2}{c|}{ Siklus III } \\
\hline 1 & 4 & 50 & 5 & 62,50 & 7 & 87,50 & 8 & 100,00 \\
\hline 2 & 3 & 37,50 & 4 & 50,00 & 6 & 75,00 & 7 & 87,50 \\
\hline 3 & 3 & 37,50 & 5 & 62,50 & 7 & 87,50 & 8 & 100,00 \\
\hline 4 & 4 & 50 & 6 & 75,00 & 7 & 87,50 & 8 & 100,00 \\
\hline 5 & 3 & 37,50 & 4 & 50,00 & 6 & 75,00 & 7 & 87,50 \\
\hline 6 & 2 & 25,00 & 5 & 62,50 & 6 & 75,00 & 7 & 87,50 \\
\hline 7 & 5 & 62,50 & 6 & 75,00 & 7 & 87,50 & 8 & 100,00 \\
\hline 8 & 3 & 37,50 & 5 & 62,50 & 7 & 87,50 & 8 & 100,00 \\
\hline 9 & 2 & 25,00 & 4 & 50,00 & 6 & 75,00 & 7 & 87,50 \\
\hline 10 & 4 & 50 & 5 & 62,50 & 7 & 87,50 & 8 & 100,00 \\
\hline
\end{tabular}




\begin{tabular}{|c|c|l|c|c|c|c|c|}
\hline Jumlah & 412,5 & & 612,50 & & 825,00 & & 950,00 \\
\hline Rata-rata & 41,25 & & 61,25 & & 82,5 & & 95,00 \\
\hline
\end{tabular}

Dari tabel 10 diatas terlihat bahwa perolehan nilai keaktifan belajar siswa yaitu :

1. Pada observasi Pra Siklus Nilai keaktifan belajar siswa tertinggi hanya $62,50 \%$, terendah $25 \%$ dan rata-rata keaktifan belajar siswa hanya $41,25 \%$

2. Pada observasi Siklus I Nilai tertinggi keaktifan belajar siswa $75 \%$, terendah $50 \%$ dan rata-rata keaktifan belajar siswa naik menjadi $61,25 \%$

3. Pada observasi Siklus II Nilai tertinggi keaktifan belajar siswa $87,50 \%$, terendah $75 \%$ dan ratarata keaktifan belajar siswa naik menjadi $82,50 \%$

4. Pada observasi Siklus III Nilai tertinggi keaktifan belajar siswa $100 \%$, terendah $87,50 \%$ dan rata-rata keaktifan belajar menjadi $95 \%$.

Untuk lebih jelasnya mengetahui bagaimana keberhasilan upaya guru meningkatkan keaktifan belajar siswa kelas $\mathrm{V}$ pada mata pelajaran Pendidikan Agama Islam melalui metode metafora dengan bantuan media gambar di SD Negeri 013 Pulau Kalimanting dapat diperhatikan pada gambar grafik 1.

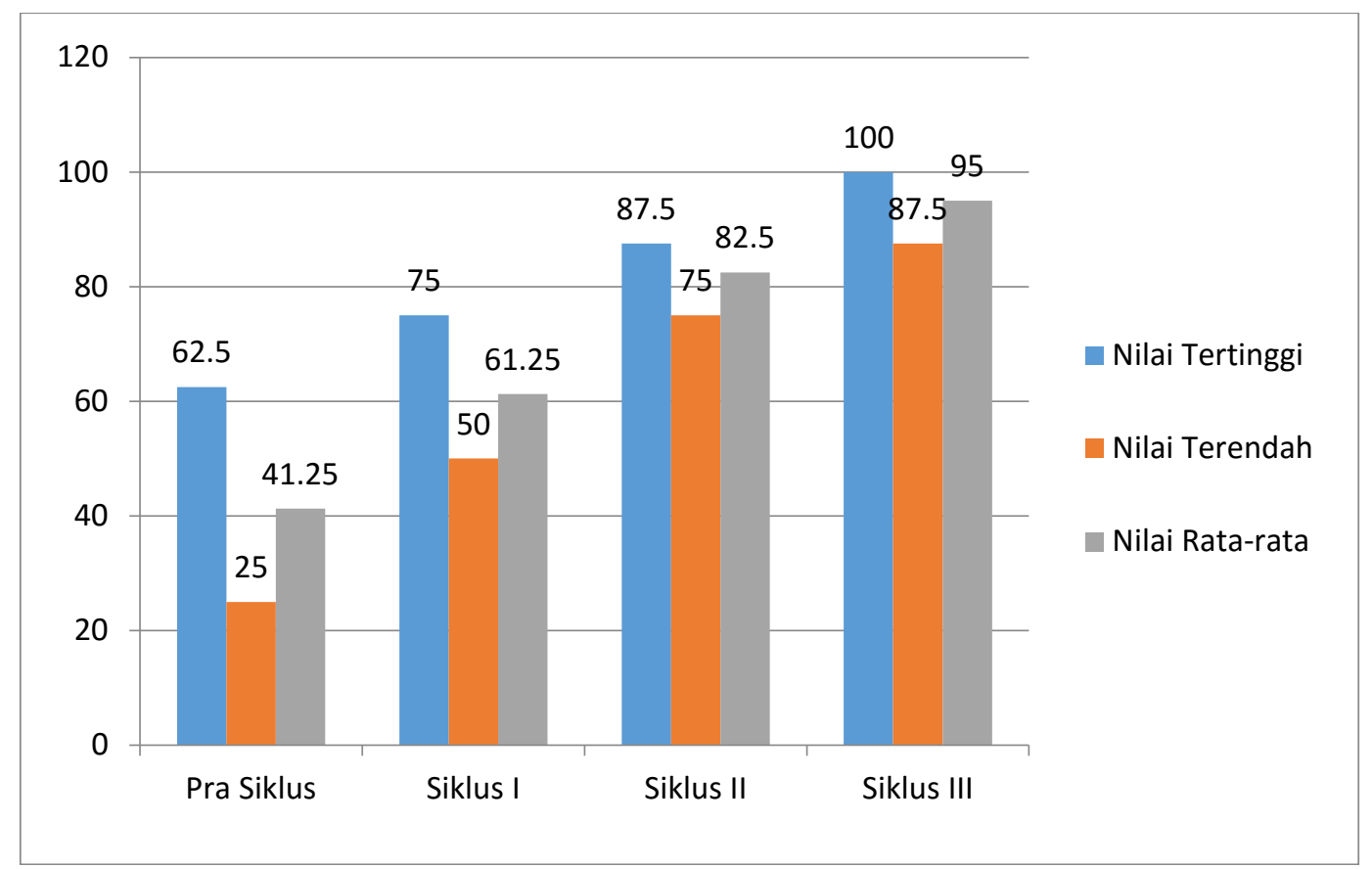

Gambar 1. Grafik Peningkatan Keaktifan Belajar PAI Siswa kelas V

\section{PENUTUP}

Berdasarkan hasil tes dan pengamatan dari setiap siklusnya dapat diambil kesimpulan bahwa penerapan metode metafora dengan bantuan media gambar dapat meningkatkan keaktifan belajar siswa pada mata pelajaran PAI di SD Negeri 013 Pulau Kalimanting Kecamatan Benai, hal ini dibuktikan sejak Pra Siklus Nilai keaktifan belajar siswa tertinggi hanya $62,50 \%$, terendah $25 \%$ dan rata-rata keaktifan belajar siswa hanya $41,25 \%$. Pada Siklus I Nilai tertinggi keaktifan belajar siswa $75 \%$, terendah $50 \%$ dan rata-rata keaktifan belajar siswa menjadi $61,25 \%$. Pada Siklus II Nilai tertinggi $87,50 \%$, terendah $75 \%$ dan rata-rata keaktifan belajar siswa naik menjadi $82,50 \%$. Pada Siklus III Nilai tertinggi keaktifan belajar siswa $100 \%$, terendah $87,50 \%$ dan rata-rata keaktifan belajar siswa naik menjadi $95 \%$.

\section{UCAPAN TERIMAKASIH}

Peneliti mengucapkan terima kasih kepada Universitas Negeri Islam Kuantan Singingi Riau, STAIN Bengkalis, Sekolah Dasar Negeri 013 Pulau Kalimanting Kecamatan Benai, LPPM STKIP 
Nurul Huda Sukaraja OKU Timur dan Tim Jurnal Al l'tibar Program Studi PAI STKIP Nurul Huda.

\section{DAFTAR PUSTAKA}

FX Sudarsono. (2001). Aplikasi Penelitian Tindakan Kelas. Jakarta: Departemen Pendidikan Nasional Margono. (2004). Metodologi Penelitian Pendidikan. Jakarta: PT Rineka Cipta

Melvin L. Silberman. (2004). Active Learning: 101 Cara Belajar Aktif. Bandung: Nusa Media \& Nuansa.

Mustaqim dan Abd. Wahab. (2010). Psikologi Pendidikan. Jakarta: Rineka Cipta.

Rena Wellek dan Austian Warren. (2010). Theory of Literature, terj. Melani Budianta, Teori Kesusastraan. Jakarta: PT Gramedia.

Suharsimi Arikunto. (2008). Prosedur Penelitian Suatu Pendekatan Praktek. Bandung: Humaniora.

Syaiful Bahri Djamarah. (2000). Guru Dan Anak Didik. Jakarta: Rineka Cipta 